\title{
Requirements for Brand Managers and Product Managers Responsible for Competitiveness of Product and Brands
}

\author{
- Wroblowská Zuzana
}

\begin{abstract}
Competitiveness of a product and care of a brand value are mainly the work of product managers and brand managers who play a major role in creating a competitive advantage of their companies. The aim of the paper is to present partial results of an independent research and connect them with the knowledge base of knowledgable management and human factors in product management. The paper focuses on a set of requirements for qualifications, experience, knowledge and skills that are imposed on candidates for the position of "Brand Manager". For the purposes of defining the research objectives, an assumption was made that a set of requirements for candidates will prove that brand managers and product managers are knowledgable workers. In order to meet this goal, the method of content analysis of job advertisements was used. Secondly, the research was focused on identifying and analysing the differences between the sets of requirements for product managers and brand managers. The analysis of the texts of job advertisements resulted in the requirements for knowledge and competency. It provided the information about what level of education, type and length of practical experience was preferred for the position of "Brand Manager". The unexpected result was that the groups of technical knowledge and work experience of brand managers and product managers had statistically significant differences. At the end of the article, there are a number of recommendations formulated for the implementation of recruitment strategy.
\end{abstract}

Keywords: brand manager, competitiveness, buman resources, knowledge, product management, recruitment strategy, skills

JEL Classification: D83, M12, M31, M51

\section{INTRODUCTION}

With many of the undoubted social changes, marketing of business organizations is currently being confronted with a new reality which requires new knowledge and skills of the marketing staff. It is a challenge to discover whether and how the changes are reflected in the issue of human factors in product management and to focus on brand managers because these kinds of open positions permanently attract graduates and marketers with work experience.

To create the concept of product management as an interdisciplinary function within the firm, the key role is played by the employee with the title of "Product Manager" or "Brand Manager". It is important to determine whether product categories are being developed within the specific organization in the parts of plans of the portfolio products or brands. As an integrated system of planning, budgeting and implementation activities, brand management was mainly put through 
by the manufacturers of products for consumer markets. On B2B markets, they pay attention to the brands primarily as a seal of quality and utility that allows the company to protect its intellectual property and promote itself on the market.

The role of the chief brand officer has emerged in business and has been described, but the responsibility for making the brand decisions every day still rests on the shoulders of brand managers in most companies. The involvement of brand managers in internal company processes is rather complex and, in the hierarchy of the company, another worker or a group of workers is rarely subordinate to the brand manager. Thanks to the use of tools of marketing tactics, $\mathrm{s} / \mathrm{he}$ should be able to build a strong position for the product brands s/he was entrusted with. The brand manager has to understand the tendencies in the development of products and services market, and by improving her/his personal performance, consistently strengthen the competitiveness of the organization and increase its chances of success in the future. In order to succeed, $\mathrm{s} /$ he must have knowledge and personal attributes.

The researched issues are characterized by the lack of input data since brand managers do not do the jobs according to qualification standards. In a corporate practice, this job function can vary to some extent in its content and demands. This fact was taken into consideration in the selection of primary sources.

A set of demands for educational, professional and general competencies, knowledge and skills, experience and expertise with which the candidates for the position of "Brand Manager" are confronted with at the beginning of the recruitment process, is also used to identify the shifts in demands. For this purpose, there has been used a unique set of data from 2007 prior to the outbreak of the financial crisis in the US, which influenced not only product and service markets, but also the labour force in the EU and the Czech market as an integral part of it. Moreover, the consistent application of the methods of content analysis, which was first published by Wroblowská (2011), allows us to compare the requirements imposed on brand and product managers.

\section{OBJECTIVES AND METHODOLOGY}

\subsection{Purpose and methodology}

The goal of the paper is to present partial results of an independent research and to connect them with a knowledge base which relates to human factors in product management and an output in the form of recommendations for the strategy and implementation of the recruitment process and to provide inspiration to those who are responsible for professional training of future brand managers.

While addressing the raised issues, an interdisciplinary approach was applied, as the knowledge of a theoretical background and the analysis of the current state of issues and the tendencies of its development required to conduct a research in several fields of study. The methods used in the research were partly empirical (primary research) and partly logical, particularly using deduction when working with secondary data, analysis and synthesis. The determination of research assumptions proceeded from a knowledge base. To verify the hypotheses, the method of comparison was also used, the results of which were examined by the test of independence of variables. 


\subsection{Scientific aim}

The primary goal of the research project was to examine the situation of "Brand Manager" positions offered on the researched labour market and to provide answers to the questions arising from the research assumptions. The research project has been drawn up to examine the assumption that a brand manager is an example of a knowledgable worker and is seen as such by the business practice. The secondary objective was to identify whether with the passing of the years, there has been a shift in demands imposed on candidates for the position of "Brand Manager", and finally, to compare and identify differences in requirements for product managers and brand managers. For this purpose, the following assumptions have been made:

- the set of requirements for candidates for the job of a brand manager will confirm that a brand manager is one of the workers who have knowledge, skills and experience,

- employers at the stage of economic recovery do not lower requirements for the new workers to be qualified for the position of "Brand Manager",

- as for the requirements for the level of education, knowledge and expertise, brand managers and product managers do not differ.

The research project was designed in such a way that it would be possible to compare the outputs of the primary research with the results of partial stages of the research project by Wroblowská (2011). Therefore, the validated content analysis method has been used according to the concept of Bernard Berelson (1952), who defined it as the research method for the objective, systematic and quantitative description of the content of the text. The information on the requirements for applicants for the position of a Brand Manager in the Czech Republic was taken from the publicly available recruitment advertising on the career portal Jobs.cz. The data collection took place in the odd weeks from February to April and from June to August 2015. Thus 86 adverts were gathered with the exclusion of ads supplemented with adjectives "senior" or "junior" and after that, four adverts were excluded because the job responsibilities did not correspond to the functional characteristics of product management. After removing duplicates, the final sample showed 56 advertisements.

Data processing has been applied in a manner consistent with the procedure referred to in the dissertation by Wroblowská (2011) which provided an input for the results comparison between 2007 and 2014 and analysed differences between the requirements for filling positions of Brand Manager and Product Manager. Data segments were transferred into an electronic form. The work with transferred data was applied to a so-called manifest content analysis according to Plichtová (1996 in Miovský, 2006) which only studies the explicit content of the text. In the categorisation of the requirements, the classification of the competencies database in the project of The National System of Professions in the Czech Republic (NSP, 2012) was taken into account. There were compared the requirements that had cumulated frequency in the analysed samples which exceeded $3 \%$ threshold in at least one of the processed data files. The statistical verification of results was made using test criteria in the chi-squared test according to Řezanková (2007).

The theoretical background and part of the discussion is based on the analysis of references which included the following three types: scientific and expert monographs and collections available in the university library under the key words "product management" and "brand management"; reviewed scientific and expert articles accessed from the EBSCO service using the key words: brand 
manager, job profile, knowledge, product manager, recruitment, and skill (Web of Science database was prioritised); and, finally, two articles publicly available on the web

\section{THEORETICAL BACKGROUND}

To complete the research task, an interdisciplinary approach was applied because the theoretical basis exceeds the boundaries of marketing as this applied study has had an intensive development and is still developing.

Assuming that at least one side is striving to satisfy the needs of the other side, marketing management according to Kotler and Keller (2012) can be approached as "the art and science of choosing target markets and getting, keeping, and growing customers' base through creating, delivering, and communicating superior customer value". From the point of view of company management, marketing can be seen as a management process which uses the resources of the whole company in order to satisfy the needs of selected groups of customers to reach the goals of both sides as the principles of marketing apply to all areas of business and their use differs only in the intensity of their application (McDonald \& Wilson, 2012).

Tomek and Vávrová (2009) emphasise that product management is an integrated product development process. Gorchels (2005) integrates brand management with product management referring to the fact that it is the most common form of product management for companies that produce consumer goods. On consumer markets, the brand management tasks are determined by the "product-brand-consumer" relationship. The dimension of the relationship is not just about how many products bring value, but mainly the value of the offers, and, therefore, success does not act only as a rational plane, but primarily the realm of emotions and feelings (Pribová et al., 2000). Kotler and Pfoertsch (2006) emphasise that on B2B markets brands fulfil the same purpose as on consumer market because "they facilitate the identification of products, services and businesses as well as differentiate them from the competition".

The starting point to derive requirements for brand managers is to state their role in the process of strategic brand management where the strategic, tactical and operative tasks are as follows: (1) identifying and establishing brand positioning, (2) planning and implementing brand marketing programmes, (3) measuring and interpreting brand performance, and (4) growing and sustaining brand equity (Keller, 2008).

In the current concept of holistic marketing, according to Kotler and Keller (2007), it is necessary to work with greater emphasis on brands and this also corresponds to the call on the commitment of top management. Gorchels (2005) points out, that managers on the top level of an organisation require further materials that would help them make decisions in matters not only of a strategic nature, but also in a number of activities that by their nature fall into the range of tactical dimension. The pressure on brand managers is growing and thus their disillusionment. Brand management system is often criticized. For example, Kumar (2008) notes that brand managers who fail are too focused on the short-term goals and do not have the authority which could help them be seen as business partners by retailers. Gorchels (2005) explains that the cause of it is not human factors, but the choice of the enterprise competitive strategy. 
Brand managers in their coordinating role should prove their ability to gain over other functional sectors to perform the tasks and maintain product integrity which is integrated into the entrusted to them brand. According to Gorchels (2005), more importance to their expertise is given on $\mathrm{B} 2 \mathrm{~B}$ markets. However, it is indisputable that the employment eligibility of brand managers and the added value of brand management process have a causal connection similar to the relation between employment eligibility of a product manager and added value of the product management process, as described by Wroblowská (2011, 2012a).

The added value that people can contribute to an organization is emphasized by human capital theory (Schultz, 1961 in Armstrong, 2012). Human capital theory is associated with the resourcebased view of a company as developed by Barney (1991 in Armstrong, 2006). This suggests that sustainable competitive advantage is attained when a company has a human resource pool that cannot be imitated or substituted by its rivals. At the same time, human capital represents the combined intelligence, skills, and expertise that give an organization its distinctive characters (Bontis, 1999 in Armstrong, 2012).

A high level of education and specialist skills combined with the ability to apply skills to identify and solve problems are distinguishing characteristics of knowledge workers (Drucker, 1993). Knowledge workers do not form a homogeneous group. In a corporate organization, there may be multiple types of knowledge workers next to each other. Mládková (2008) pointed out that you can distinguish between those who produce knowledge and those who are responsible for knowledge transfer. Davenport and Prusak (2000) developed the topic of "working knowledge" and concluded that knowledge can be transformed into innovations and then competitiveness. Other authors continued these studies in conditions of certain organizations. For example, Pitra, Mohelská et al. (2015) stressed the importance of a suitable corporate culture for knowledge application. Púčková (2015) focused on the importance of knowledge about customers for a successful brand positioning. Thanks to the combination of the knowledge of customers and knowledge held by employees, companies can personalise their products. Product personalisation is one of the ways to increase competitiveness (Tomek \& Vávrová, 2009).

One of the targets of this research paper is to contribute to an improvement of overall orientation of labour market participants through the outcomes of the research project which is accompanied by recommendations for the process of recruitment of brand managers. It starts with the definition of knowledge, skills and competencies necessary for work or/and with the definition of education, qualifications, training and experience that are required for the acquisition of the necessary knowledge and competencies (Armstrong \& Taylor, 2015).

\section{RESULTS}

This paper presents and discusses data and results which are directly related to the paper's goal. The final results of the research project, their discussion and possible applications are now being processed. Partial results related to product managers and requirements for knowledge, specialised and strategic skills and transferable general competencies were presented to the experts in the paper published by Wroblowská and Ruda (2015a). 


\subsection{Secondary data applied in the research project}

In the discussion of findings, the available empirical surveys conducted outside the Czech Republic will be mentioned. When preparing the independent research, no new information was available from the empirical research which meant to research the human factor in product management in the Czech Republic apart from those which had been published already, see Wroblowská (2011, 2012b, 2012c).

\subsection{Content analysis and comparison of requirements in job advertisements}

The source of requirements for candidates for the position of "Brand Manager" were job advertisements on Jobs.cz, the most popular career portal in the Czech Republic, which was already verified by Wroblowská (2011) as a suitable source to fulfil the research goal. The job position had a different name, for example, "Junior Brand Manager" or "Senior Brand Manager", the advertisement was not included in the sample in that case. In 2007, when applying the same selection procedure, the sample of single adverts reached the number of 34 , and in 2015 , there were 56 advertisements. The sorted data from the researched advertisement texts are presented in a form of frequency chart in Table 1. At the same time, the table gives the information about the results of the survey carried out by Wroblowská (2011) between 2006 and 2007.

Tab. 1 - Comparison of requirements for a brand manager by advertisers in 2007 and 2015. Source: Independent research

\begin{tabular}{|c|c|c|c|c|c|}
\hline \multirow{2}{*}{\multicolumn{2}{|c|}{ Group }} & \multicolumn{2}{|c|}{2007} & \multicolumn{2}{|c|}{2015} \\
\hline & & \multicolumn{2}{|c|}{ Brand manager } & \multicolumn{2}{|c|}{ Brand manager } \\
\hline \multicolumn{2}{|r|}{$\begin{array}{c}\text { Technical knowledge and skills and } \\
\text { general }\end{array}$} & $\begin{array}{l}\text { Abs. } \\
\text { frequency }\end{array}$ & $\begin{array}{l}\text { Relative } \\
\text { frequency }\end{array}$ & $\begin{array}{l}\text { Abs. } \\
\text { frequency }\end{array}$ & $\begin{array}{l}\text { Relative } \\
\text { frequency }\end{array}$ \\
\hline \multicolumn{6}{|c|}{ requirements for education } \\
\hline \multirow{3}{*}{ G } & university & 17 & $50,0 \%$ & 35 & $62,5 \%$ \\
\hline & high school or university & 13 & $38,2 \%$ & 13 & $23,2 \%$ \\
\hline & $\begin{array}{l}\text { high school or higher technical } \\
\text { education, not university }\end{array}$ & 1 & $2,9 \%$ & 5 & $8,9 \%$ \\
\hline \multicolumn{6}{|c|}{ technical knowledge and skills } \\
\hline \multirow{4}{*}{$\mathrm{H}$} & knowledge of technical disciplines & 7 & $20,6 \%$ & 7 & $12,5 \%$ \\
\hline & $\begin{array}{l}\text { knowledge of brand/product man- } \\
\text { agement }\end{array}$ & 1 & $2,9 \%$ & 4 & $7,1 \%$ \\
\hline & knowledge of marketing & 3 & $8,8 \%$ & 5 & $8,9 \%$ \\
\hline & $\begin{array}{l}\text { knowledge of project management } \\
\text { preferable }\end{array}$ & 2 & $5,9 \%$ & 4 & $7,1 \%$ \\
\hline
\end{tabular}




\begin{tabular}{|c|c|c|c|c|c|}
\hline \multicolumn{6}{|c|}{ general, transferable competencies } \\
\hline & excellent Czech & 0 & $0,0 \%$ & 6 & $10,7 \%$ \\
\hline & $\begin{array}{l}\text { communicative knowledge of DE } \\
\text { or FR }\end{array}$ & 2 & $5,9 \%$ & 0 & $0,0 \%$ \\
\hline & excellent English & 7 & $20,6 \%$ & 27 & $48,2 \%$ \\
\hline \multirow[t]{3}{*}{$\mathrm{J}$} & $\begin{array}{l}\text { good/advanced/communicative } \\
\text { English }\end{array}$ & 22 & $64,7 \%$ & 18 & $32,1 \%$ \\
\hline & $\begin{array}{l}\text { work with PC/with MS Office on a } \\
\text { good level }\end{array}$ & 11 & $32,4 \%$ & 24 & $42,9 \%$ \\
\hline & driver's license of Czech cat. B & 14 & $41,2 \%$ & 25 & $44,6 \%$ \\
\hline \multicolumn{6}{|c|}{ required practice and work experience } \\
\hline \multirow{9}{*}{ K } & work experience in sales & 0 & $0,0 \%$ & 5 & $8,9 \%$ \\
\hline & $\begin{array}{l}\text { professional experience with prov- } \\
\text { able results }\end{array}$ & 1 & $2,9 \%$ & 12 & $21,4 \%$ \\
\hline & work experience in marketing & 11 & $32,4 \%$ & 18 & $32,1 \%$ \\
\hline & experience in the field preferable & 8 & $23,5 \%$ & 11 & $19,6 \%$ \\
\hline & experience in the field necessary & 4 & $11,8 \%$ & 12 & $21,4 \%$ \\
\hline & professional experience & 5 & $14,7 \%$ & 10 & $17,9 \%$ \\
\hline & $\begin{array}{l}\text { experience with this position at } \\
\text { least } 2 \text { years }\end{array}$ & 9 & $26,5 \%$ & 18 & $32,1 \%$ \\
\hline & $\begin{array}{l}\text { experience with this position } 3 \\
\text { years and more }\end{array}$ & 4 & $11,8 \%$ & 13 & $23,2 \%$ \\
\hline & $\begin{array}{l}\text { experience with leading a team/a } \\
\text { smaller work group }\end{array}$ & 3 & $8,8 \%$ & 0 & $0,0 \%$ \\
\hline
\end{tabular}

In accordance with a recognized expert opinion that the knowledge worker is characterized not only by his/her training and expertise, but also by his/her experience, the part of presented output are also requirements for working experience of applicants for the vacant position of "Brand Manager".

Figure 1 illustrates that the representation of the characters in some groups differs according to evaluation requirements, with the exception of general and transferable competencies which were marked with "J" during the data processing, the changes in the representation of the requirements in individual groups are statistically insignificant, see table 2. 
experience with leading a team/a smaller work group experience with this position 3 years and more experience with this position at least 2 years professional experience experience in the field necessary
experience in the field preferable
work experience in marketing experience in the field necessary
experience in the field preferable
work experience in marketing experience in the field necessary
experience in the field preferable
work experience in marketing professional experience with provable results
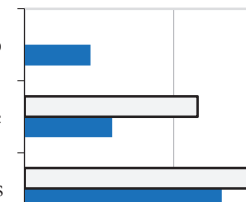
work experience in sales work with PC/with MS Office on a good level good/advanced/communicative English

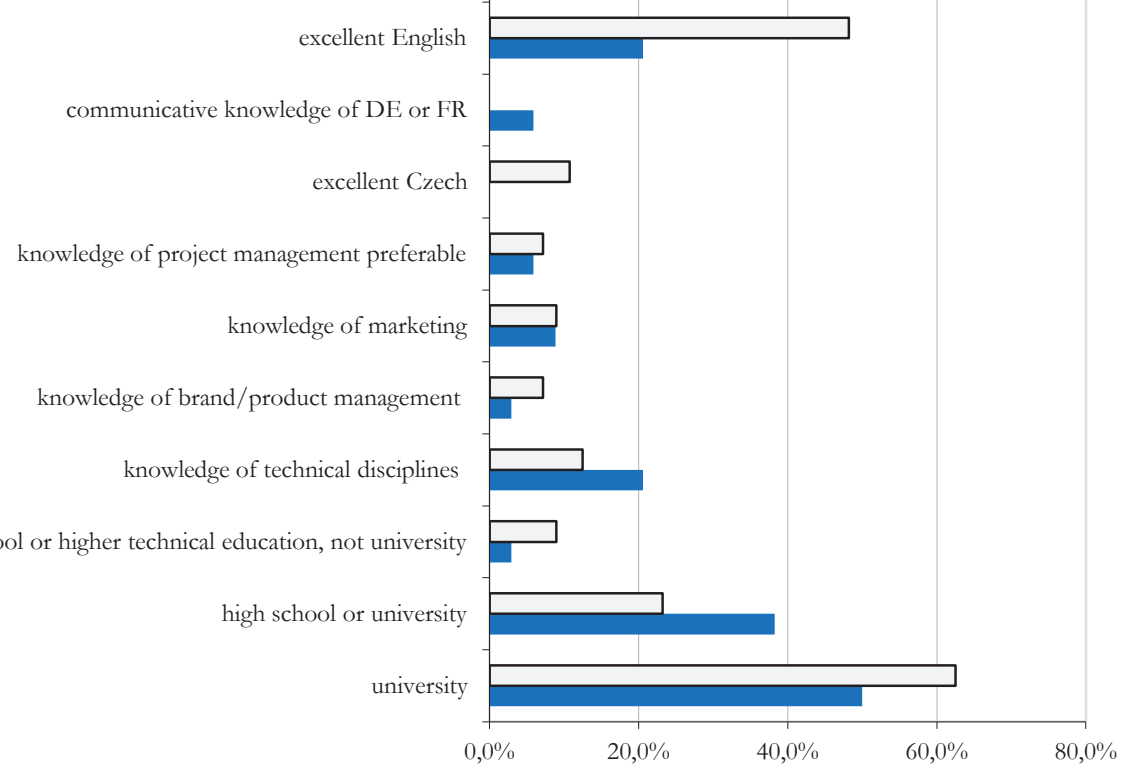

high school or higher technical education, not university

high school or university $0,0 \%$
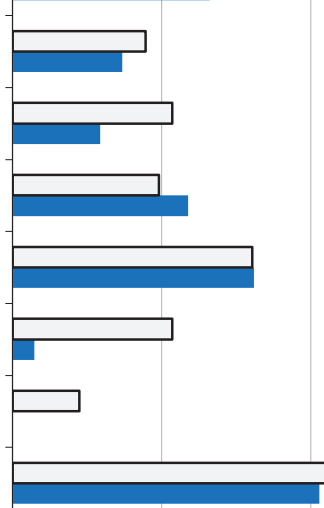

ㅁBM 2015

- BM 2007

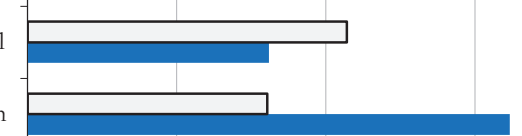

$$
\text { h }
$$


The test criterion was the $\chi^{2}$ test. On the significance level of $0.1 \%, 1 \%$, and $5 \%$, it was tested whether the null hypothesis regarding independence of the analysed variable on the sign representing the year of the content analysis of advertisements can or cannot be rejected.

Tab. 2 - Overview of results of individual requirement groups testing. Source: Independent research

\begin{tabular}{|l|l|l|c|l|}
\hline & the group of tested requirements & $\begin{array}{l}\text { chi-square } \\
\text { value }\end{array}$ & df & test result \\
\hline G & requirements for education & 3,964153877 & 2 & $\mathrm{H}_{0}$ not rejected \\
\hline H & technical knowledge and skills & 1,551634615 & 3 & $\mathrm{H}_{0}$ not rejected \\
\hline J & general, transferable competencies & 17,04126771 & 5 & $\mathrm{H}_{0}$ rejected \\
\hline K & required practice and work experience & 14,72279766 & 8 & $\mathrm{H}_{0}$ not rejected \\
\hline
\end{tabular}

A statistically significant difference in the distribution of requirements for general, transferable competencies was confirmed for both $\&=0.01$ and $\&=0.05$.

Table 3 gives information about the comparison of the two analysed data files: advertisements for the position of "Product Manager" in 2014 and advertisements for candidates for the position of "Brand Manager" in 2015.

Tab. 3 - Comparison of requirements for brand managers (in 2015) and for product managers (in 2014). Source: Independent research

\begin{tabular}{|c|c|c|c|c|c|}
\hline \multirow{2}{*}{\multicolumn{2}{|c|}{ Group of requirements }} & \multicolumn{2}{|c|}{2014} & \multicolumn{2}{|c|}{2015} \\
\hline & & \multicolumn{2}{|c|}{ Product manager } & \multicolumn{2}{|c|}{ Brandmanager } \\
\hline \multicolumn{2}{|r|}{$\begin{array}{l}\text { Technical knowledge and skills } \\
\text { and general competencies }\end{array}$} & $\begin{array}{c}\text { Abs. } \\
\text { frequency }\end{array}$ & $\begin{array}{l}\text { Relative } \\
\text { frequency }\end{array}$ & $\begin{array}{l}\text { Abs. } \\
\text { frequency }\end{array}$ & $\begin{array}{l}\text { Relative } \\
\text { frequency }\end{array}$ \\
\hline \multicolumn{6}{|c|}{ requirements for education } \\
\hline \multirow{3}{*}{ G } & university & 55 & $55,0 \%$ & 35 & $62,5 \%$ \\
\hline & high school or university & 24 & $24,0 \%$ & 13 & $23,2 \%$ \\
\hline & $\begin{array}{l}\text { high school or higher technical } \\
\text { education, not university }\end{array}$ & 12 & $12,0 \%$ & 5 & $8,9 \%$ \\
\hline \multicolumn{6}{|c|}{ technical knowledge and skills } \\
\hline \multirow{4}{*}{$\mathrm{H}$} & $\begin{array}{l}\text { knowledge of technical disci- } \\
\text { plines }\end{array}$ & 34 & $34,0 \%$ & 7 & $12,5 \%$ \\
\hline & $\begin{array}{l}\text { knowledge of brand/product } \\
\text { management }\end{array}$ & 13 & $13,0 \%$ & 4 & $7,1 \%$ \\
\hline & knowledge of marketing & 8 & $8,0 \%$ & 5 & $8,9 \%$ \\
\hline & $\begin{array}{l}\text { knowledge of project manage- } \\
\text { ment preferable }\end{array}$ & 2 & $2,0 \%$ & 4 & $7,1 \%$ \\
\hline
\end{tabular}




\begin{tabular}{|c|c|c|c|c|c|}
\hline \multicolumn{6}{|c|}{ general, transferable competencies } \\
\hline \multirow{6}{*}{$\mathrm{J}$} & $\begin{array}{l}\text { communicative knowledge of } \\
\text { DE or FR }\end{array}$ & 2 & $2,0 \%$ & 0 & $0,0 \%$ \\
\hline & excellent English & 28 & $28,0 \%$ & 27 & $48,2 \%$ \\
\hline & $\begin{array}{l}\text { good/advanced/communicative } \\
\text { English }\end{array}$ & 57 & $57,0 \%$ & 18 & $32,1 \%$ \\
\hline & excellent Czech & 8 & $8,0 \%$ & 6 & $10,7 \%$ \\
\hline & $\begin{array}{l}\text { work with PC/with MS Office } \\
\text { on a good level }\end{array}$ & 35 & $35,0 \%$ & 24 & $42,9 \%$ \\
\hline & driver's license of Czech cat. B & 32 & $32,0 \%$ & 25 & $44,6 \%$ \\
\hline \multicolumn{6}{|c|}{ required practice and work experience } \\
\hline \multirow{10}{*}{ K } & $\begin{array}{l}\text { professional experience with } \\
\text { provable results }\end{array}$ & 13 & $13,0 \%$ & 12 & $21,4 \%$ \\
\hline & work experience in sales & 2 & $2,0 \%$ & 5 & $8,9 \%$ \\
\hline & work experience in marketing & 11 & $11,0 \%$ & 18 & $32,1 \%$ \\
\hline & experience in the field preferable & 17 & $17,0 \%$ & 11 & $19,6 \%$ \\
\hline & experience in the field necessary & 54 & $54,0 \%$ & 12 & $21,4 \%$ \\
\hline & professional experience & 4 & $4,0 \%$ & 10 & $17,9 \%$ \\
\hline & $\begin{array}{l}\text { experience with this position at } \\
\text { least } 2 \text { years }\end{array}$ & 18 & $18,0 \%$ & 18 & $32,1 \%$ \\
\hline & $\begin{array}{l}\text { experience with this position } 3 \\
\text { years and more }\end{array}$ & 23 & $23,0 \%$ & 13 & $23,2 \%$ \\
\hline & $\begin{array}{l}\text { experience with this position at } \\
\text { least } 5 \text { years }\end{array}$ & 12 & $12,0 \%$ & 0 & $0,0 \%$ \\
\hline & $\begin{array}{l}\text { experience with leading a team/a } \\
\text { smaller work group }\end{array}$ & 1 & $1,0 \%$ & 0 & $0,0 \%$ \\
\hline
\end{tabular}

Table 4 is prepared for the set of requirements for professional knowledge and professional skills that are in Table 3 classified as the group H. It demonstrates the statistical verification procedure and the result of applying the independence test. A statistically significant difference in the distribution of requirements for technical knowledge and skills was confirmed for $\&=0.05$, as proven by calculations in Table 4. 
Tab. 4 - Two-dimensional analysis for a group of requirements for technical knowledge and professional skills. Source: Independent research

\begin{tabular}{|l|c|c|c|}
\hline OVERALL CONCLUSION: The significance level of 5\% rejects the null hypothesis; the \\
$\begin{array}{l}\text { Probability distribution of the individual characters does not differ in groups "brand } \\
\text { managers" (2015) and "product managers" (2014). }\end{array}$ & $\mathbf{0 , 1 \%}$ & $\mathbf{1} \%$ & $\mathbf{5} \%$ \\
\cline { 2 - 4 } & $\begin{array}{c}\text { cannot } \\
\text { refuse }\end{array}$ & $\begin{array}{c}\text { cannot } \\
\text { refuse }\end{array}$ & refuse \\
\hline
\end{tabular}

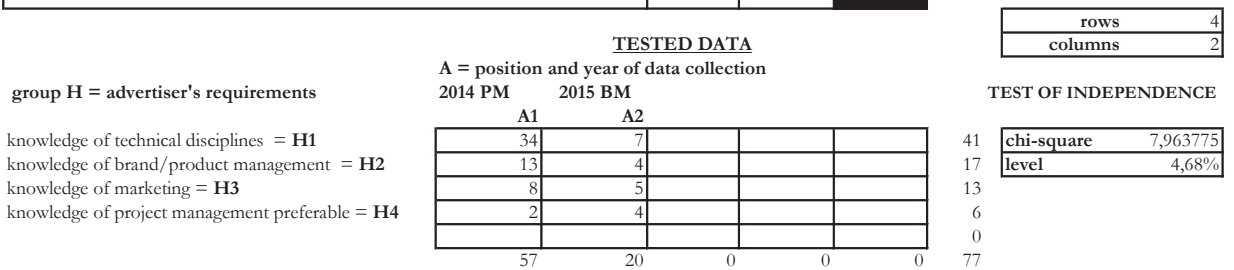
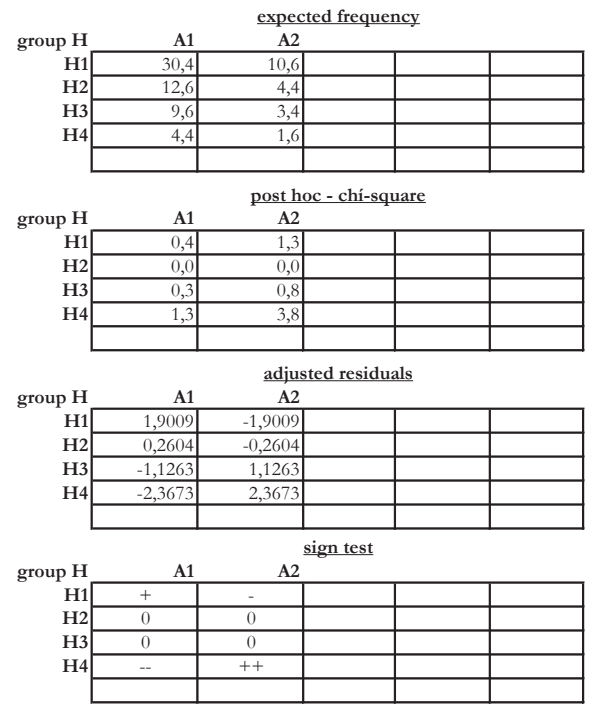

Besides the requirements for professional knowledge and skills, the statistical verification process confirmed the differences in a set of requirements for the practical experience of candidates for the positions of Brand Manager and Product Manager for $\&=0.001$.

\section{DISCUSSION FINDINGS AND RECOMMENDATIONS}

The results presented in Chapter 4.2 are directly linked to the objectives set in Chapter 2. Thanks to the experience gained from the research project implemented by Wroblowska (2011) in the phase of economic recovery before the onset of the global economic crisis, the job descriptions were carefully reviewed in the posted advertisements so that the analysed group could include only the advertisements for vacant positions within the structures supporting the product planning and management. In this way, we can discuss a job role in product management. Although experts attributed the role of a coordinator to brand managers and product managers, Wrob- 
lowská $(2011,2012$ c) pointed out that in real practice the role of brand managers as implementers of marketing plans prevailed in the Czech Republic.

Now, the results will be analysed and the degree of fulfilment of the research assumptions and objectives will be evaluated. In 2015, the requirement for having a higher education degree occurred in the analysed advertisements 35 times. It was demanded by more than $50 \%$ of advertisers. The requirement for the educational degree occurred in $95 \%$ of advertisements.

The second highest frequency was recorded in the requirement for an excellent knowledge of the English language, and that is $27 \mathrm{x}(48.2 \%)$. On the contrary, the requirements from the category of professional knowledge and skills are stated in the texts of advertisements significantly less often. You cannot overlook the fact that for the given position they are looking for workers with experience and this experience is defined in the published advertisements in different ways, thereby reducing the resulting frequency of individual characters.

The findings show that the assumptions that the brand manager is one of those who possesses professional knowledge, skills and experience, and, as a knowledge worker, is seen by corporate practice as problematic. In the texts of the advertisements, it was rarely mentioned where or in what field the candidate should receive his/her education. It is, therefore, a matter of discussion whether advertisers assume that a successful completion of university education proves that the graduate has demonstrated his/her intellectual flexibility and is not only equipped with the acquired knowledge and professional skills, but is also prepared for his/her further education, as stated by Pitra, Mohelská et al. (2015).

The intellectual flexibility and the ability for lifelong learning are among the characteristics of a knowledge worker (Truneček, 2003). It can, therefore, be concluded that the advertised requirements for higher education and experience replace the explicitly formulated requirements for professional knowledge and skills, as mentioned by Armstrong and Taylor (2015).

The discussion regarding the second assumption according to the purpose of the article will be linked to the statement that we pointed out some of the differences. There was a statistically significant shift in the set of general, transferable competencies. At present, a higher level of knowledge of the English language is required, while the interest in the German language has decreased and the requirement for the excellent knowledge of the Czech language has newly appeared. It could be, therefore, concluded that the employers have not lowered their requirements for brand managers, at least as far as hard skills and working experience are concerned, when the above mentioned term "hard skills" has the opposite meaning of the term "soft skills", which in some academic works and, especially, in human resources practice is connected to a group called "soft skills" which is used to describe the behavioural competencies and personality traits possessed by an individual, which nourish these competencies.

As all the aspects of modern business are influenced by an increased globalization, there is no surprise that advanced or excellent English is in the set of requirements for brand managers. Hollensen (2011) emphasized that experience and a positive attitude towards international processes together with corresponding skills determine the competitiveness in the international business environment. Nevertheless, to fulfil the tasks on the Czech national market needs an excellent Czech for understanding the customers' needs and feelings, creating and communicat- 
ing the value for customers. There is the way how to improve market knowledge and marketing knowledge, which is absolutely important for building strong brands. Thus, this is the way of applying learning methods in the company. It is mainly coaching by a marketing manager and market research manager according to Armstrong (2012). The author's findings regarding technical knowledge and skills correspond to the idea of internal learning methods.

The third research assumption that in terms of requirements for the level of education, knowledge and professional skills, brand managers and product managers have no differences was not proved by the results. Brand managers have to prove their experience in the process of recruitment and demonstrate their experience in marketing more often. On the other hand, the request to show the knowledge of the advertiser's field and/or industries of his/her customers occurred less often. The filling of "Brand Manager" position is more often subject to less than three years' working experience. The advertisement requiring the proof of at least five years' practical experience for the position has not occurred at all and for the positions of Product Manager it was mentioned in 12 cases. The knowledge of the technical discipline and knowledge of brand/ product management were greatly emphasised.

To verify what knowledge the product managers should have was one of the research objectives of Tyagi and Sawhney (2010). During the analysis of the sample of 198 product managers, they found out the overshadowing of marketing knowledge and the elevation of product knowledge. Moreover, the authors stated in the characteristics of the sample that the participants of the research worked as product managers on average 7.4 .

For the purposes of meeting the targets of this article, it may be formulated that the positions of Brand Manager and Product Manager are intended primarily for workers who are prepared to make their knowledge available to employers and who are able to receive, develop and apply new knowledge. The author refers to the articles by Wroblowska and Ruda (2015a, 2015b) in which the findings regarding product managers are discussed in more detail.

For the successful performance of marketing jobs, Kotler and Keller (2013) recommend to grasp the current challenges and flip them for the success of their products and brands on the market, which also means a greater and more effective use of the Internet as the information and sales channel, grasping social media and using it for emphasizing brand messages, communicating with customers through blogs, supporting online communities and using the stir created by brand ambassadors in their communities. Brand managers must have the specific knowledge and skills for these activities.

Although the requirements for applicants for open positions in brand management have rarely been referred to as explicitly stated experience in digital marketing and "knowledge of Internet communications", one can conclude that the e-recruitment strategy will be effective because the candidates are open for the recruitment process with the use of online communication (Wroblowská, 2016). Recruitment adverts in newspapers and magazines only allow advertisers to say a few words. The adverts which are on advertisers' corporate websites and on employment websites are more comprehensive, but since these adverts clearly contain 100 percent of advertising content, they are sometimes not viewed by the reader as being authentic and credible. And, finally, about 80 percent of the population that is not actively looking for a job simply will not 
even glance at them. Thus conventional adverts generally work for active jobseekers only. A combination of various methods of e-recruiting, including effective job posts on job boards, makes a very effective strategy. In order to capture the attention of those who are the best, but who are possibly not looking for a job actively, it is appropriate to accompany the advertisement with podcasts and boost the visibility of the one who offers a job on social networks of professionals, primarily LinkedIn.

With reference to the research paper of Connie Barrow (2014), it is recommended to the advertisers, in order to get a productive person that the competitors would like to have in their team, they must not only attract a suitable candidate, but also "get him to the action." The ways that appear as effective can be associated with the term "native ads". The native ads fit to several categories. One of them is "paid search" when advertisements appear during a standard search on the website. On Google, they appear in the right hand column.

The fact is that "native ads" are actually viewed more frequently and their readers are more fully engaged when reading them because they contain useful information. Sullivan (2016) mentioned in his article that more recruiting leaders are aware that "native ads" will become the mainstream in recruiting.

Finally, greater attention to the selection process is not addressed in the article. Nevertheless, the author suggests readers to consider the inclusion of an expensive complex method of Assessment Centre and the behavioural interview. If the results and experience of the applicants are generally serious criteria for suitability for the job of a brand manager for the advertisers, it is important not only to lay down the criteria on the spot, but also to fairly evaluate them. These two methods are recommended to determine the candidates' self-marketing and uncover to what extent the candidates' successes and ambitions are based on their personal qualities. These methods significantly reduce the effect of self-marketing behaviour of candidates.

\section{CONCLUSION}

This paper deals with the specific issues that were examined by way of an empirical research project. Its long-term objective was to gather and analyse information about the requirements that are imposed on candidates for the position of "Brand Manager". This research project was initiated by the author's interest in human resources in the field of product management as brand managers have an important role in striving for competitiveness.

Since the implementation of the research in 2015 in which the method of content analysis of adverts for filling the position of "Brand Manager" was applied, it was expected to confirm that the business community perceives brand managers as knowledgable workers and they prefer candidates with knowledge, professional skills and qualifications for filling vacant positions in product management, which is a sign that the knowledgable workers will be able to expand their knowledge in practice. The interest of advertisers in candidates with working experience, holders of a university degree and who are also multilingual and IT literate shows that the category of knowledgable workers includes brand managers, though the frequency of requirements for technical knowledge and skills does not correspond to it. 
The most published requirement in the analysis of sample advertisements in 2015 was the attainment in higher education (62.5\%). The same kind of requirement, if we do not evaluate claims and requirements for the soft skills, dominated in ads in 2007 when the economy of the Czech Republic was also in the phase of boom. During the comparison, there were recorded some differences. A statistical verification confirmed the shift of requirements in the group of general transferable competencies. In 2015, the requirements in this group did not require another world language rather than English which was more often required at both advanced and excellent levels. The greatest number of advertisements contained the requirement for IT-skills of the applicant. The research assumption has not proved that in the analysed groups of requirements, the groups of data from the analysis of advertising for the position of a product manager and brand manager will not differ. By applying the test of independence, in which the test criterion of chi-square distribution was chosen, there were differences in the group of "required practice and work experience" confirmed for $\&=0.001, \&=0.01$, and $\&=0.05$.

For brand manager's positions, a shorter period of work experience (less than 2 years) is significantly more often acceptable. Advertisers are not looking for brand managers with at least 5 years' experience, as compared to product managers. They are more likely to search for candidates with experience in marketing and less often with experience acquired in the field of the employer. In advertisements for the position marked "Brand Manager", the relative frequency of requirements for the demonstration of tangible results in the previous position of the applicant exceeds greatly.

The latter findings led the author to complement and broaden the recommendations for recruitment of brand managers by incorporating financially more demanding, but significantly more reliable methods of Assessment Centre and behavioural interview to follow-up the selection process.

This article can be used as a source of inspiration for of the bearers of professional training of future managers as well as human resource managers as the positions in marketing are among those that are permanently being advertised and finding the most appropriate candidate is associated with considerable requirements for human and financial resources. The author carries out her research on job advertising in the USA where the concept of brand management has its roots, and it is expected that subsequent to its completion, it will be possible to examine the issue of human resources in product management in a new context.

\section{Acknowledgement}

This paper was elaborated with the support of the Banking Institute / College of Banking Research Centre.

\section{References}

1. Armstrong, M., \& Taylor, S. (2015). Řizené lidských zdrojü: modernípojetí a postupy. Praha: Grada Publishing.

2. Armstrong, M. (2012). Armstrong's Handbook of Human Resource Management Practice. London: Kogan Page.

3. Armstrong, M. (2006). A Handbook of Human Resource Management Practice. London: Kogan Page. 
4. Berelson, B. (1952). Content Analysis in Communication Research. Glencoe III.: The Free Press.

5. Barrow, C. (2014). You'll Think I'm Crazy, but You Should Put This in Job Ads. Retrieved from http://www.ere.net/2014/09/02/youll-think-im-crazy-but-you-should-put-this-in-jobads/\#more-40039.

6. Davenport, T. H., \& Prusak, L. (2000). Working Knowledge: How Organisations Manage what They Know. Boston: Harvard Business Review Press.

7. Drucker, P. F. (1993). Post-capitalist Society. Oxford: Butterwort-Heinemann.

8. Gorchels, L. (2005). The Product Managers Handbook. New York: McGraw-Hill.

9. Hollensen, S. (2011). Global Marketing: A Decision-oriented Approach. London: Prentice Hall.

10. Keller, L. K. (2008). Strategic brand management: building, measuring, and managing brand equity. New Jersey: Pearson Education.

11. Kotler, P., \& Keller, L. K. (2013). Marketing management. Praha: Grada Publishing.

12. Kotler, P., \& Keller, L. K. (2012). Marketing management. New Jersey: Prentice Hall.

13. Kotler, P., \& Keller, L. K. (2007). Marketing management. Praha: Grada Publishing.

14. Kotler, P., \& Pfoertsch, W. (2006). B2B Brand Management. Berlin: Springer.

15. Kumar, N. (2008). Marketing jako strategie vedoucí k úspèchu. Praha: Grada Publishing.

16. McDonald, M., \& Wilson, H. (2012). Marketingový plán: př̈prava a úspěšná realizace. Brno: BizBooks.

17. Miovský, M. (2006). Kvalitativníprǐstup a metody psychologickébo výžkumu. Praha: Grada Publishing.

18. Mládková, L. (2008). Management żnalostních pracovníkì. Praha: C. H. Beck.

19. NSP. Databáze kompetencí. (2012). Retrieved from: http://kompetence.nsp.cz/

20. Pitra, Z., Mohelská, H., et al. (2015). Management transferu żalostí: od pruního nápadu ke komerčnè úspěšné inovaci. Praha: Professional Publishing.

21. Přibová, M., Mynářová, L., Hindls, R., \& Hronová, S. (2000). Strategické rízení značkey. Praha: Ekopress.

22. Púčková, K. (2015). Knowledge and Main Factors of Brand Success. Marketing Science \& Inspirations, 10 (1), 42-48.

23. Řezanková, H. (2007). Analýza dat z dotazníkových šetrení. Praha: Professional Publishing.

24. Sullivan, J. (2016) Native Advertising — The Next Big Thing In Recruitment Advertising. Eremedia. Retrieved from http://www.eremedia.com/ere/native-advertising-the-next-bigthing-in-recruitment-advertising/

25. Tomek, G., \& Vávrová, V. (2009). Jak zvýsít konkurenčni schopnost firmy. Praha: C. H. Beck.

26. Truneček, J. (2003). Znalostni podnik ve znalostni společnosti. Praha: Professional Publishing. 
27. Tyagi, R. K., \& Sawhney M. S. (2010). The Impact of Structure, Process, Competencies, and Role Definition. Journal of Product Innovation Management, 27 (1), 83-96.

28. Wroblowská, Z. (2016). Lidské zdroje v produktovém managementu. Praha: Professional Publishing.

29. Wroblowská Z., \& Ruda, T. (2015). Identifikace požadavků kladených na produktové manažery v procesu náboru. Marketing Science \& Inspirations, 10 (1), 9-21.

30. Wroblowská Z., \& Ruda, T. (2015). The Identification and Comparison of the Requirements Placed on Product Managers during the Recruitment Process. Journal of Competitiveness, 7 (3), 110-125. DOI: 10.7441/joc.2015.03.08

31. Wroblowská, Z. (2012 a). Efektivita produktového managementu. Moderní rízenení, 47 (2), 25-27.

32. Wroblowská, Z. (2012b). Identifikace role produktového manažera a vytvoření standardní typové pozice Produktový manažer. Trendy ekonomiky a managementu, 6 (11), 98-108.

33. Wroblowská, Z. (2012c). Lidský faktor v brand managementu. Marketing Science \& Inspirations ,7 (2), 25-39.

34. Wroblowská, Z. (2011). Lidský faktor v produktovém managementu. Disertační práce, Vysoká škola báňská - Technická universita Ostrava, Ostrava.

\section{Contact information}

RNDr. Zuzana Wroblowská, Ph.D.

Banking Institute/College of Banking

Department of Business and Evaluation

Nárožni 2600/9, 15800 Praha 5,

Czech Republic

e-mail:zwroblowska@bivs.cz. 